\title{
Genetic Heterogeneity of Cebocephaly
}

\author{
LEWIS B. HOLMES, SHIRLEY DRISCOLL, and LEONARD ATKINS
} From the Genetics Unit, Children's Service and the fames Homer Wright Memorial Laboratories and Department of
Pathology at the Massachusetts General Hospital, the Department of Pathology of the Boston Hospital for Women, and the Departments of Pediatrics and Pathology and Center for Human Genetics of Harvard Medical School, Boston, USA

Summary. Three infants with cebocephaly with entirely different aetiologies are described: one possibly representing the effect of a single mutant gene, one with apparent $\mathrm{E}$ trisomy, and one with $\mathrm{D}$ trisomy. In comparison with other reported patients, it is likely that infants with cebocephaly and no associated chromosomal abnormality have few, if any, extracranial malformations.

The malformed infant who dies soon after birth often does not have a careful diagnostic evaluation. In our experience these infants often have genetic diseases the aetiology of which may be a chromosomal abnormality, a polygenic disorder, or a single mutant gene. An example of such a fatal malformation with diverse genetic causes is cebocephaly, a disorder which includes brain and facial anomalies, the most striking of which are holotelencephaly and a cylindrical nose with a single nostril. This disorder has been described in infants who had a normal karyotype (DeMyer, 1964; James and van Leeuwen, 1970; Warkany, 1971 and 1972), as well as in infants with several different chromosomal abnormalities, including 47, XX, +13 (McKusick, 1961 ; von Bühler et al, 1962; Conen, Erkman, and Metaxotou, 1966), 46,XX,18p - (Uchida et al, 1965; Gorlin, Yunis, and Anderson, 1968), 46,XX, 18r (Neu et al, 1972), and 47,XX, + C (Lejeune et al, 1969). One of the infants with normal chromosomes had a similarly affected sib, raising the possibility that cebocephaly might in some instances be due to a single mutant gene (James and van Leeuwen, 1970).

We have studied three infants with cebocephaly, each of whom had an apparently different genetic aetiology: one infant had a normal karyotype and a sister with holotelencephaly; one had an extra chromosome which may represent (17-18) E-group trisomy although this could not be definitely proven and one had a chromosome $D$ trisomy. The

Received 19 February 1973.

* Supported in part by grants from the Charles H. Hood Foundation (Boston), and the Massachusetts Developmental Disabilities Council, NIH Special Fellowship Number 1 FO3 HD-53, 606-01 and Children's Bureau Project Number CB-12-HSP-906. associated physical features of these infants also confirm the suggestion of DeMyer (1964) that individuals with cebocephaly and a normal chromosome karyotype usually do not have malformations in areas other than the face, cranium, and brain.

\section{Case Histories}

Case 1 was born in 1971 after an uneventful full-term pregnancy to a 27-year-old mother and a 33-year old father; birth weight was $3 \mathrm{~kg}$. She had poor spontaneous respirations at birth and expired after 5 hours. Head circumference was $30.5 \mathrm{~cm}$; heel to crown length was $44.5 \mathrm{~cm}$. There was marked hypotelorism [inner/outer canthal widths $=1.8 / 3.9 \mathrm{~cm}$, which are below normal (Pryor, 1969)] and a soft cylindrical structure in place of a nose (Fig. 1). Her palpebral fissures were narrow and eyelids and supraorbital ridges were hypoplastic. She had a small mouth and no philtrum of her upper lip. The nasal opening ended blindly at $1 \mathrm{~cm}$ depth. She had a centrally cleft palate that extended the full length of the palate. Her ears were not malformed. She had no limb anomalies, except for mild clinodactyly of each fifth finger (Fig. 1). Her anus and external genitalia were normal.

Necropsy showed absence of both a cribriform plate and crista galli, a single optic foramen, no midline cleft in the cerebral mantle (Fig. 2), and a single lateral ventricle. The posterior aspect of the brain was covered by a thin transparent membrane. No basal ganglia, thalamus, or pyramidal tracts could be seen. The pituitary was smaller than that of a normal newborn and on sectioning only neuroglial cells were present. The adrenal glands were extremely thin, weighing $2 \mathrm{~g}$ together [expected weight of both adrenals at this birth weight $9.8 \mathrm{~g}$ (Potter, 1961)].

Chromosome analysis on the patient (leucocytes and skin fibroblasts) and her parents showed no abnormali35 

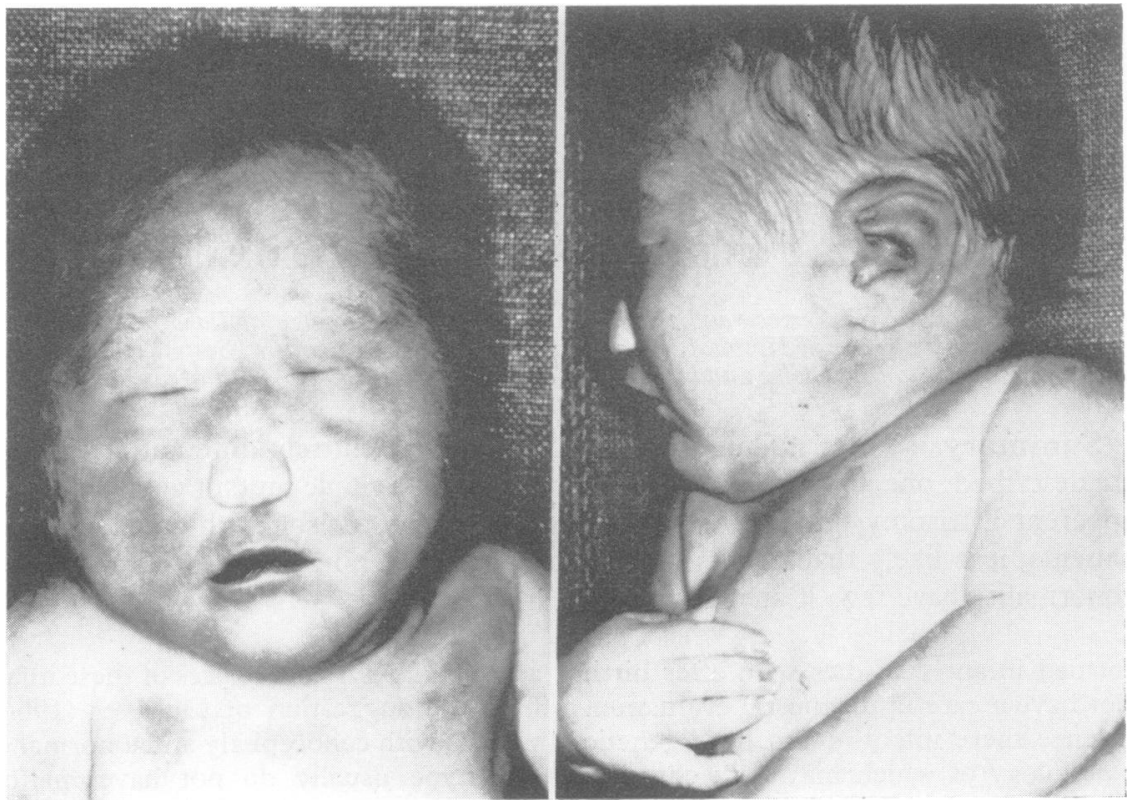

Fig. 1. Case 1. Note the hypotelorism, small nose, and absence of philtrum. The clinodactyly of the fifth finger of one hand is also visible.

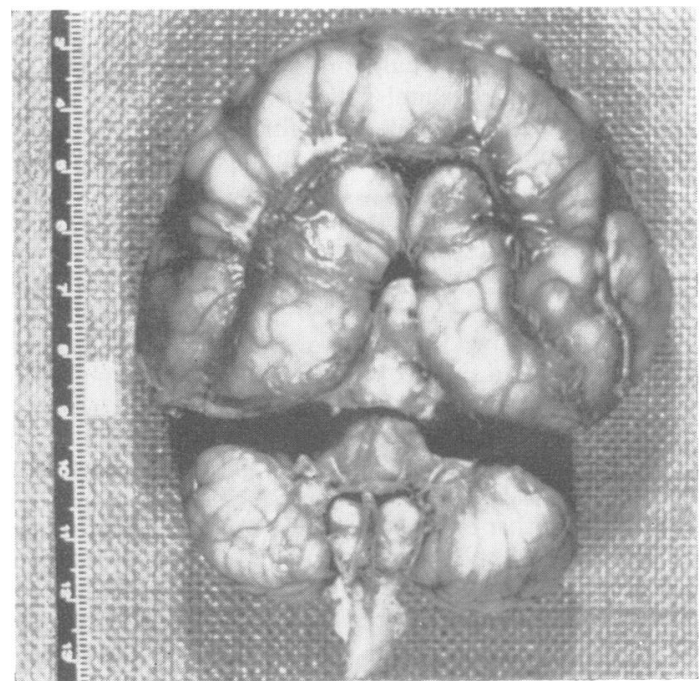

FIG. 2. Case 1. The brain showing the failure of division of the forebrain and the lack of olfactory bulbs and tracts. normal girl and the other a sister with holotelencephaly, who is described below. There is no consanguinity or any other family member with craniofacial anomalies.

The malformed sister of patient 1 was born in 1967 . The pregnancy and delivery were uncomplicated. She died soon after birth; birth weight was $1.8 \mathrm{~kg}$, length was $42 \mathrm{~cm}$, and head circumference $25 \mathrm{~cm}$. No photographs were taken of the child. The father recalls that she looked like patient 1 , but the pathologist noted that her nose was normal. At necropsy* she had no anomalies, except those involving the cranium and brain. The forebrain was rounded and not divided into hemispheres. The parietal and occipital lobes were smaller than normal. The aqueduct of Sylvius was not present. The peduncles were not differentiated. The lateral fascicles of the medulla oblongata had an abnormal appearance. She also had a patent ductus arteriosus.

Case 2 was born in 1971 to a 25-year-old mother and 24-year-old father. The pregnancy was complicated by vaginal bleeding at 12 weeks' gestation. The infant was delivered by Caesarean section at 36-37 weeks gestation because of a small maternal pelvic inlet. The pla-

* Necropsy findings kindly provided by Dr A. Huaman, Topeka, Kansas. 
centa weighed $120 \mathrm{~g}$ and showed no abnormalities other than its very small size. The umbilical cord contained three vessels. The infant had an Apgar of 3 at 1 minute and 2 at $5 \mathrm{~min}$ after birth. His respirations were laboured and he died at 4 hours of age. Birth weight was $1.6 \mathrm{~kg}$, crown-rump length $27.5 \mathrm{~cm}$, and head circumference $27.5 \mathrm{~cm}$.

The physical features included: hypotelorism (inner/ outer canthal widths $=1 \cdot 3 / 4.0 \mathrm{~cm}$ ), narrow palpebral fissures, a soft tubular nose with a single nostril, small ears with overfolded helices (Fig. 3), no philtrum of upper lip, highly arched palate, short sternum $(3.5 \mathrm{~cm})$, an um- bilical hernia, a short phallus $(1.0 \mathrm{~cm})$, a flat non-rugated scrotum (Fig. 4), tapering fingers, a transverse paimar crease in the right hand, small toenails and short, dorsiflexed great toes (Fig. 5).

Necropsy findings included: fused frontal bones, holotelencephaly with a single cerebral ventricle, hypoplasia of the cerebral peduncles, and small cerebellum, pontine fibres, temporal horns, and hippocampus. Microscopic examination of the pituitary gland showed no abnormalities. The adrenal glands weighed $3.5 \mathrm{~g}$ [expected weight $5 \mathrm{~g}$ (Potter, 1961)]. The internal genitalia showed two immature testes located in the abdomen,
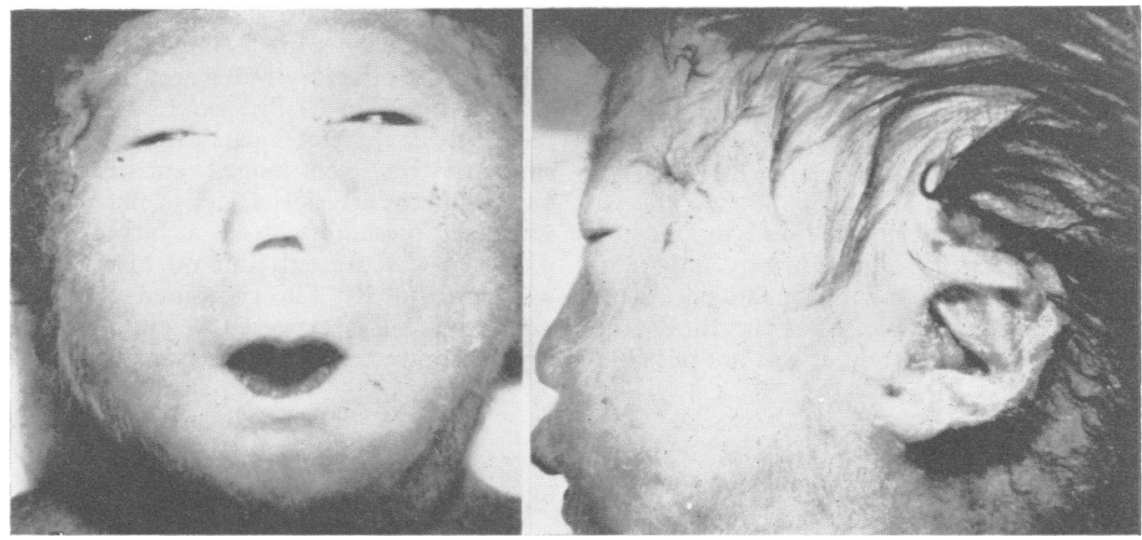

Fig. 3. Case 2. The single nostril, hypotelorism, and small ears.

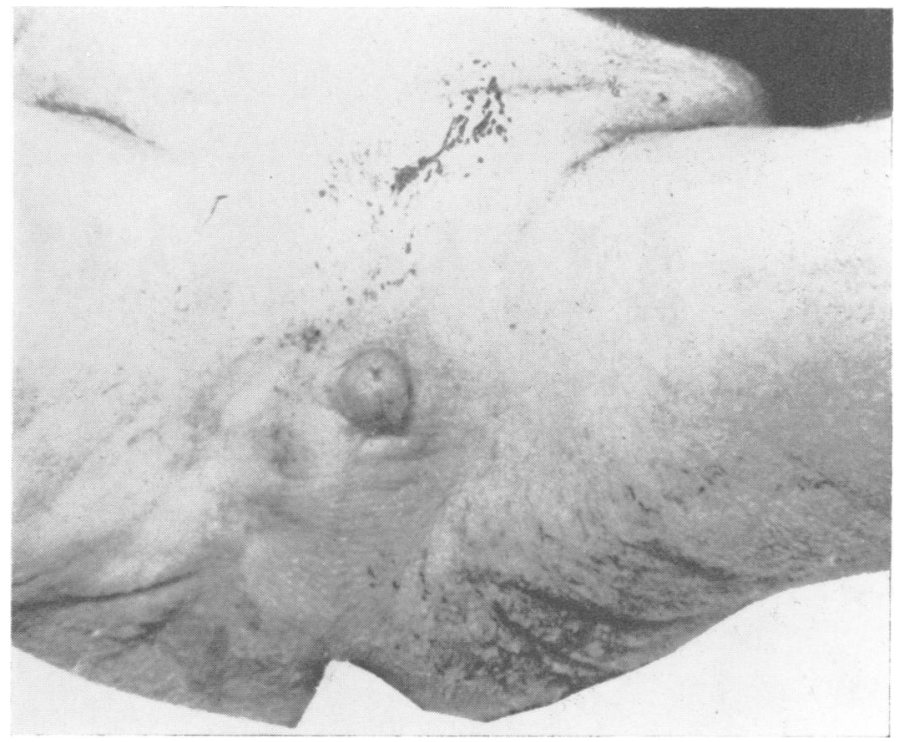

Fig. 4. Case 2. The short phallus and non-rugated scrotum. 


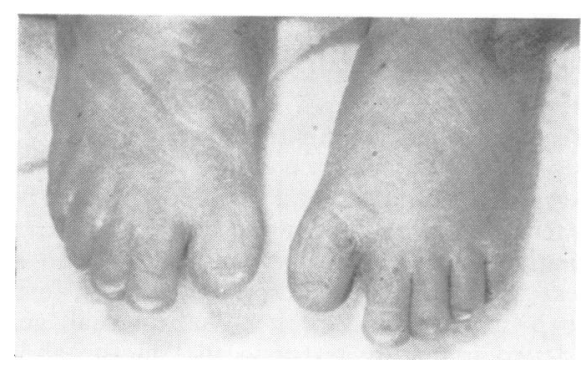

FIG. 5. Case 2. The short great toes and small nails.

two epididymes, two oviducts, and a unicornate uterus with a single cervix. The heart was dextroposed, had a ventricular septal defect, hypoplastic left atrium, and anomalous pulmonary venous return. Radiology showed a small cranium, orbital hypotelorism, shallow orbits, abnormal sternal ossification, and ossification of each calcaneus.

Chromosome analysis was performed on lymphocytes obtained shortly before death. Unfortunately, only four metaphase plates were adequate for evaluation. Each showed an extra chromosome (Fig. 6) in the E (17-18) group $(47, \mathrm{XX},+\mathrm{E})$. Unfortunately, it was not possible to study the E-group chromosomes with either quinacrine fluorescence or other staining techniques. Chromosome analysis from leucocytes of the parents showed no abnormalities.

Case 3, a stillborn female, was born in 1961. Her mother, age 23 years, developed 'acute hydramnios' at 34 weeks gestation and delivered this infant spontaneously at that time. A previous pregnancy had resulted in a normal child.

The placenta was small and oedematous. The umbilical cord was short and contained two vessels (one artery and one vein). Birth weight was $1.5 \mathrm{~kg}$, crownrump length $29 \mathrm{~cm}$, and head circumference $28 \mathrm{~cm}$. The necropsy findings included: brain weight $77 \mathrm{~g}$, holotelencephaly with a single cerebral ventricle, $a b-$ sence of the olfactory bulbs and tracts, optic nerves and chiasm, circle of Willis, cerebral peduncles and pyramids, an incomplete sella turcica, microphthalmia, a single nostril $1.5 \mathrm{~cm}$ long, a ventricular septal defect and patent ductus arteriosus, lack of fixation of the caecum, a universal mesentery, and a bicornuate uterus. The pituitary was present, but no histological examination was performed. The combined weight of the adrenal glands was $9 \cdot 2 \mathrm{~g}$ (expected weight $5 \mathrm{~g}$ together). Radiographs showed that the anterior fossa was more oblique

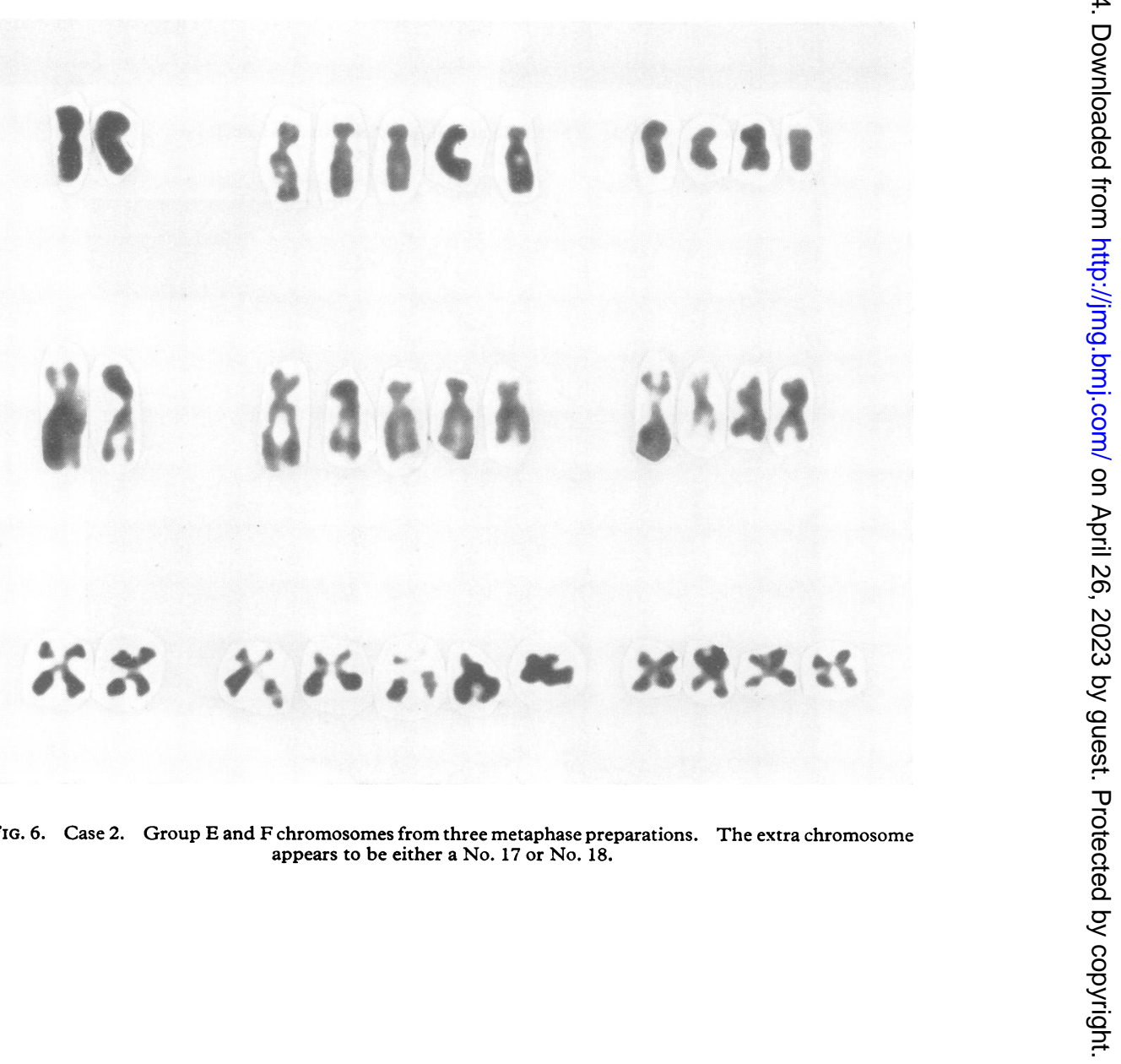


than usual. Chromosome analysis using skin fibroblasts showed D trisomy $(47, \mathrm{XX},+\mathrm{D})$ in all metaphase preparations.

\section{Discussion}

All of the reported infants with cebocephaly (McKusick, 1961; Bühler et al, 1962; DeMyer, 1964; Uchida et al, 1965; Conen et al, 1966; Gorlin et al, 1968; Lejeune et al, 1969; James and van Leeuwen, 1970; Warkany, 1971; Neu et al, 1972; Warkany, 1972), as well as our three patients, have had holotelencephaly and the associated cerebral abnormalities often found in individuals with holotelencephaly (Yakovlev, 1959). In addition, infants with cebocephaly often have absence, and abnormal development, of the pituitary; endocrine gland; hypoplasia, genital underdevelopment that is most noticeable in males, and a cleft or highly arched palate (Table I). Presumably the small adrenal and thyroid glands and the small penis and undescended testes of males are the result of hormonal deficiencies. Deficiencies of pituitary hormones have not been proven in infants with cebocephaly, but have been documented in infants with a similar malformation, holotelencephaly with cleft lip and palate (Hintz, Menking, and Sotos, 1968). The cleft palate is apparently a feature of the abnormal craniofacial development in infants with cebocephaly.

In evaluating infants with cebocephaly it is their associated extracranial anomalies which seem to reflect their different genetic aetiologies. Each of the four infants with a normal chromosome karyo-

TABLE I

COMPARISON OF PHYSICAL FEATURES OF REPORTED PATIENTS AND THE THREE IN THIS STUDY*

\begin{tabular}{|c|c|c|c|c|c|c|}
\hline \multirow{2}{*}{ Reference Source } & \multirow{2}{*}{ Sex } & \multirow{2}{*}{$\begin{array}{l}\text { Pituitary } \\
\text { and } \\
\text { Adrenal } \\
\text { Glands } \\
\text { Either } \\
\text { Absent } \\
\text { or } \\
\text { Abnormal } \\
\end{array}$} & \multirow{2}{*}{$\begin{array}{l}\text { Small } \\
\text { Penis } \\
\text { and } \\
\text { Crypt- } \\
\text { orchidism }\end{array}$} & \multirow{2}{*}{$\begin{array}{c}\text { Palate } \\
\text { Either } \\
\text { Cleft } \\
\text { or } \\
\text { Abnormal }\end{array}$} & \multicolumn{2}{|c|}{ Extracranial Anomalies } \\
\hline & & & & & External & Internal \\
\hline $\begin{array}{l}\text { Cebocephaly with normal karyotype } \\
\text { James and van Leeuwen (1970) }\end{array}$ & M & + & + & & Inguinal hernia & \\
\hline DeMyer (1964) & $\mathbf{M}$ & & + & & Bilateral simian crease & \\
\hline Warkany $(1971 ; 1972)$ & F & + & & + & & $\begin{array}{l}\text { Hydronephrosis due to } \\
\text { ureteral narrowing }\end{array}$ \\
\hline Present case 1 & $\mathrm{~F}$ & + & & + & Clinodactyly of fifth fingers & \\
\hline $\begin{array}{l}\text { Cebocephaly with abnormal karyoty } \\
\text { C trisomy } \\
\text { Lejeune et al (1969) }\end{array}$ & ? & & & & $\begin{array}{l}\text { Malformed ears; small } \\
\text { chin; elongated thorax; } \\
\text { enlarged liver }\end{array}$ & \\
\hline $\begin{array}{l}13 \text { trisomy } \\
\text { McKusick (1961) } \\
\text { Buhler et al (1962) } \\
\text { Conen et al (1966) }\end{array}$ & $\begin{array}{l}\mathrm{F} \\
\mathrm{F}\end{array}$ & & & + & $\begin{array}{l}\text { Anophthalmos; deformed } \\
\text { ears } \\
\text { Polydactyly; ulnar } \\
\text { deviation of hands } \\
\text { Scalp defects; malformed } \\
\text { eyes and ears }\end{array}$ & $\begin{array}{l}\text { Ventricular septal defect } \\
\text { Ventricular septal defect; } \\
\text { diaphragmatic hernia; } \\
\text { septate uterus; intestine } \\
\text { incompletely rotated } \\
\text { Multiple cardiac anomalies }\end{array}$ \\
\hline $\begin{array}{l}\mathrm{D} \text { trisomy } \\
\text { Present case } 3\end{array}$ & $\mathbf{F}$ & & & & $\begin{array}{l}\text { Microphthalmia; single } \\
\text { umbilical artery }\end{array}$ & $\begin{array}{l}\text { Ventricular septal defect; } \\
\text { universal mesentery; } \\
\text { bicornuate uterus }\end{array}$ \\
\hline $\begin{array}{l}\text { 18p- } \\
\text { Uchida et al (1965) } \\
\text { Gorlin et al (1968) }\end{array}$ & $\begin{array}{l}\mathbf{F} \\
\mathrm{F}\end{array}$ & $\begin{array}{l}+ \\
+\end{array}$ & & $\begin{array}{l}+ \\
+\end{array}$ & $\begin{array}{l}\text { Inverted feet; dorsiflexed } \\
\text { little toes } \\
\text { Microphthalmia }\end{array}$ & $\begin{array}{l}\text { Fissured spleen and } \\
\text { accessory spleen } \\
\text { Colon incompletely rotated }\end{array}$ \\
\hline$\stackrel{18 r}{\text { Neu et al }(1972)}$ & $\mathrm{F}$ & $\mathrm{i}$ & & + & $\begin{array}{l}\text { Large ears; partial } \\
\text { aniridia }\end{array}$ & $\begin{array}{l}\text { Small thymus; multiple } \\
\text { cardiac anomalies }\end{array}$ \\
\hline $\begin{array}{l}\mathrm{E}(\underset{17-18)}{ }) \text { trisomy } \\
\text { Present case } 2\end{array}$ & $M$ & ! & + & + & $\begin{array}{l}\text { Small ears; short sternum; } \\
\text { umbilical hernia; } \\
\text { tapering fingers; simian } \\
\text { crease; short dorsiflexed } \\
\text { great toes }\end{array}$ & $\begin{array}{l}\text { Two testes; two oviducts; } \\
\text { unicornuate uterus; } \\
\text { ventricular septal defect; } \\
\text { anomalous pulmonary } \\
\text { venous return }\end{array}$ \\
\hline
\end{tabular}

* A plus sign is used to indicate some of the features; the absence of the plus sign indicates lack of information in original report. 
type had only one associated malformation two of which were minor in nature [transverse palmar creases (James and van Leeuwen, 1970) and clinodactyly of the fifth fingers-bilateral in the present case 1] and two were major [inguinal hernia (DeMyer, 1964) and unilateral hydronephrosis (Warkany, 1971 and 1972)]. In assessing the significance of a single minor anomaly, it should be noted that in one study (Marden, Smith, and McDonald, 1964) $13 \%$ of normal newborns had one minor anomaly. By contrast, the nine patients with chromosomal abnormalities had two or more different external and internal malformations (Table I). This general distinction based on there being only one or no extracranial anomalies between infants with cebocephaly and a normal chromosome karyotype and those with associated chromosomal abnormalities was first suggested by DeMyer (1964). The practical value of this observation is in terms of genetic counselling. Based on the findings of two affected children in the family of patient 1 and the family reported by James and van Leeuwen (1970), it is possible that these infants have cebocephaly as a result of their being homozygous for an autosomal recessive mutant gene. If future experience confirms these observations about associated extracranial malformations and the mode of inheritance, genetic counselling to a family can be more specific after the birth of the first infant with cebocephaly and no demonstrable chromosome abnormality.

We know that the sib of case 1 also had holotelencephaly, but we do not know if she also had cebocephaly. There is evidence that sibs with holotelencephaly need not have the same craniofacial abnormality. They may have either cebocephaly, cyclopia (fused eyes with a proboscis located above the eye), ethmocephaly (two eyes with a proboscis between them), or hypotelorism with cleft lip and palate (Hintz et al, 1968). In 1921 Klopstock reported a family in which one male infant had cebocephaly and his brother had cyclopia. The parents in this family were closely related. A family in which one infant had cyclopia and another had cebocephaly was described by Welter in 1968.

The associated external anomalies of case 2 (Table I) are similar to those reported for infants with chromosome 18 trisomy (Taylor, 1968). However, the abnormal internal genitalia are unusual. The presence of oviducts and a uterus in association with cryptorchid testes and epididymes is a rare. form of hermaphroditism. The reported patients have usually normal external genitalia, inguinal herniae, and a normal chromosome karyotype (Morillo-Cucci and German, 1971). The extracranial anomalies of case 3 are typical of the features of infants with chromosome 13 trisomy, although she does not have some of the well-known features such as cleft lip and palate, postaxial polydactyly, and scalp defects.

The data on these three infants were made available by the assistance of Drs J. Cohen, J. Meeker, E. T. HedleyWhyte, M. Rogers, A. E. Szulman, and P. Yakolev.

\section{REFERENCES}

Bühler, E. von, Bodis, I., Rossier, R., and Stalder, G. (1962). Trisomie 13-15 mit Cebocephalie. Annales Paediatrici, 199, 198205.

Conen, P. E., Erkman, B., and Metaxotou, C. (1966). The "D" syndrome. American Fournal of Diseases of Children, 111, 236247.

DeMyer, W. (1964). A 46 chromosome cebocephaly with remarks on the relation of 13-15 trisomy to holoprosencephaly (arrhinencephaly). Annales Paediatrici, 203, 169-177.

Gorlin, R. J., Yunis, J., and Anderson, V. E. (1968). Short arm deletion of chromosome 18 in cebocephaly. American fournal of Diseases of Children, 115, 473-476.

Hintz, R. L., Menking, M., and Sotos, J. F. (1968). Familial holoprosencephaly with endocrine dysgenesis. Fournal of Pediatrics, 72, 81-87.

James, E. and Leeuwen, G. van (1970). Familial cebocephaly. Case description and survey of the anomaly. Clinical Pediatrics, 9, 491-493.

Klopstock, A. (1921). Familiäres Vorkommen von Cyklopie und Arrhinencephalie. Monatsschrift für Geburtshilfe und Gynäkologie, 56, 59-71.

Lejeune, J., Dutrillaux, B., Rethoré, M. O., Berger, R., Debray, H., Veron, P., Gorce, F., and Grossiord, A. (1969). Sur trois cas de trisomie C. Annales de Génétique, 12, 28-35.

Marden, P. M., Smith, D. W., and McDonald, M. J. (1964). Congenital anomalies in the newborn infant, including minor variations. Fournal of Pediatrics, 64, 357-371.

McKusick, V. A. (1961). Medical genetics 1960. Fournal of Chronic Diseases, 14, 1-198.

Morillo-Cucci, G. and German, J. (1971). Males with a uterus and fallopian tubes, a rare disorder of sexual development. In Birth Defects: Original Articles Series, 7, Pt. 10, pp. 229-231. National Foundation-March of Dimes, New York.

Neu, R. L., Watanabe, N., Gardner, L. I., and Galvis, A. G. (1972). A single nasal orifice and severe intrauterine growth retardation in a case of 46,XX,18r. Annales de Génétique, 14, 139-142.

Potter, E. L. (1961). Pathology of the Fetus and the Newborn, 2nd ed. The Year Book Publishers, Chicago.

Pryor, H. B. (1969). Objective measurement of interpupillary distance. Pediatrics, 44, 973-977.

Taylor, A. I. (1968). Autosomal trisomy syndromes: a detailed study of 27 cases of Edward's syndrome and 27 cases of Patau's syndrome. Fournal of Medical Genetics, 5, 227-252.

Uchida, I. A., McRae, K. N., Wang, H. C., and Ray, M. (1965). Familial short arm deficiency of chromosome 18 concomitant with arhinencephaly and alopecia congenita. American fournal of Human Genetics, 17, 410-419.

Warkany, J. (1971). Congenital Malformations, p. 208. Year Book Medical Publishers, Chicago.

Warkany, J. (1972). Personal communication.

Welter, E. S. (1968). Consecutive hydrocephalics. Illinois Medical Fournal, 133, 177-179.

Yakovlev, P. I. (1959). Pathoarchitectonic studies of cerebral malformations. III. Arrhinencephalies (holotelencephalies). Fournal of Neuropathology and Experimental Neurology, 18, 22-55. 